\title{
Pemahaman Konsep Matematis Mahasiswa Menggunakan Buku Teks dengan Pendekatan Konstruktivisme
}

\author{
Alfi Yunita ${ }^{1}$, Anny Sovia ${ }^{1,2 *}$, Hamdunah $^{1}$ \\ ${ }^{1}$ Program Studi Pendidikan Matematika, STKIP PGRI Sumatera Barat \\ ${ }^{2}$ Program Studi Pendidikan Matematika, Universitas Pendidikan Indonesia \\ *annysovia@upi.edu
}

\begin{abstract}
Abstrak
Pemahaman konsep matematis merupakan suatu kemampuan yang penting untuk dikuasai oleh mahasiswa. Pemahaman konsep matematis memungkinkan peserta didik untuk memahami esensi pengajaran dan materi yang dipelajari. Tujuan penelitian adalah untuk menganalisis bagaimana pemahaman konsep matematis mahasiswa yang belajar menggunakan buku teks dengan pendekatan konstruktivisme yang sudah dikembangkan pada penelitian sebelumnya. Penelitian ini merupakan penelitian deskriptif dengan pendekatan kualitatif. Penelitian dilakukan dengan memberikan 10 butir soal pemahaman konsep kepada partisipan yang terdiri dari 17 orang mahasiswa STKIP PGRI Sumatera Barat yang sedang mengambil mata kuliah Matematika Dasar. Kemudian jawaban mahasiswa dianalisis secara deskriptif. Hasil penelitian menunjukkan bahwa pencapaian penguasaan pemahaman konsep matematis paling tinggi adalah pada indikator menggunakan model, diagram dan simbol-simbol untuk merepresentasikan suatu konsep. Sedangkan penguasaan konsep paling rendah adalah pada indikator mengenal syarat untuk menentukan suatu konsep, mahasiswa mengalami kesulitan untuk menentukan himpunan penyelesaian dari suatu pertidaksamaan nilai mutlak.
\end{abstract}

Kata kunci: buku teks, pemahaman konsep matematis, konstruktivisme

\begin{abstract}
Understanding mathematical concepts is an important ability to be mastered by students. It allows students to understand the essence of teaching and the material being learned. The purpose of the study is to analyze how mathematical concept understanding of students who learn by using constructivism-approach textbooks that have been developed in previous studies. This research was a descriptive study with a qualitative approach. The study was conducted by giving 10 item problems of conceptual understanding to participants that consisting of 17 students STKIP PGRI Sumatera Barat in Basic Mathematics subject. Furthermore, the students' answers were analyzed descriptively. The results of the study showed that a mastery achievement of the highest mathematical concept understanding was on indicators of using model, diagram, and symbols to represent a concept. While the lowest concept mastery was on indicators of recognizing conditions for determining a concept, students had difficulty in determining a settlement set from an inevitable inequality of absolute value.
\end{abstract}

Keywords: constructivism, mathematical concept understanding, text book 


\section{Pendahuluan}

Belajar dengan pemahaman merupakan tujuan penting dalam setiap subjek pelajaran, termasuk dalam pembelajaran matematika (Stylianides \& Stylianides, 2014). Pemahaman matematika sangat penting dalam belajar matematika karena akan memudahkan pemecahan masalah matematika (Minarni, Napitupulu, \& Husein, 2016). Pada taksonomi Bloom, pemahaman merupakan kemampuan berpikir yang setingkat lebih tinggi dari ingatan atau hapalan (Hendriana, Roehati, \& Sumarmo, 2017). Salah satu pemahaman yang perlu untuk dikuasai dalam belajar matematika adalah pemahaman konsep (Lambertus, 2016). Konsep itu sendiri menurut Delphie (2009) mengacu pada pemahaman dasar, peserta didik mengembangkan suatu konsep ketika mereka mampu mengklasifikasikan atau mengelompokkan benda-benda dan mampu mengasosiasikan suatu nama dengan kelompok benda tertentu. Contohnya, peserta didik mengenal konsep segitiga sebagai suatu bidang yang dikelilingi oleh tiga garis lurus. Pemahaman peserta didik tentang konsep segitiga dapat dilihat pada saat mereka mampu membedakan berbagai bentuk geometri selain segitiga. Kemudian, menurut Godino (2015) konsep merupakan kemampuan untuk mengidentifikasi objek sebagai anggota grup berdasarkan karakteristik fisik umum. Contohnya, peserta didik mengenal konsep bilangan riil sebagai suatu bilangan yang dapat dibentuk dalam desimal.

Berdasarkan observasi yang dilakukan peneliti selama mengampu mata kuliah Matematika Dasar, menentukan daerah penyelesaian dari persaamaan atau pertidaksamaan merupakan salah satu topik yang dianggap sulit dalam materi sistem bilangan riil. Hal ini didukung oleh hasil penelitian Rahmawati (2017) yang menyatakan bahwa mahasiswa melakukan banyak kesalahan dalam mengerjakan soal pertidaksamaan, salah satu hasil kerja mahasiwa dapat dilihat pada Gambar 1.

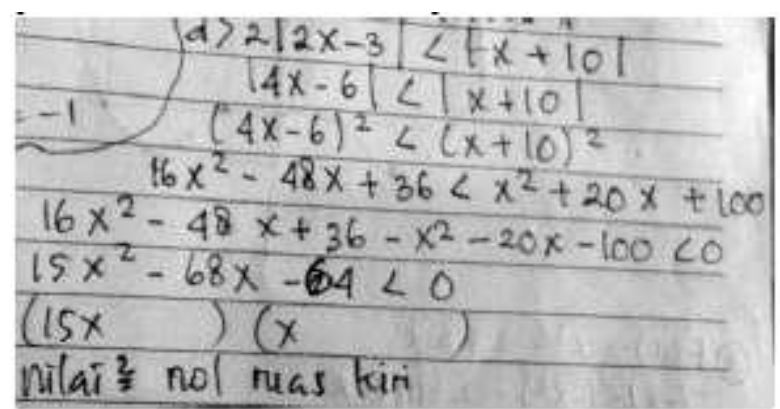

Gambar 1. Lembar Jawaban Mahasiswa (Rahmawati, 2017)

Berdasarkan Gambar 1, mahasiswa terlihat kesulitan untuk melanjutkan proses penyelesaian. Dari wawancara, mahasiswa menyatakan bahwa dia merasa kesulitan menentukan faktor- 
faktor pertidaksamaan kuadrat tersebut karena angkanya terlalu besar. Jika mahasiswa tidak dapat menentukan faktor, maka tidak akan diperoleh titik pembuat nol, hal ini berarti bahwa mahasiswa tidak bisa menentukan himpunan penyelesaian dari pertidaksamaan tersebut. Jawaban mahasiswa menunjukkan rendahnya pemahaman konsep mahasiswa pada materi sistem bilangan riil, khususnya sub materi pertidaksamaan.

Kegagalan mahasiswa dalam mempelajari matematika didasari oleh mahasiswa hanya cenderung menghapalkan konsep yang dipelajari tanpa memahami dengan benar (Amir, 2017). Idealnya materi-materi yang diajarkan kepada mahasiswa bukan hanya untuk diingat, namun lebih dari itu dengan pemahaman mahasiswa dapat lebih mengerti akan konsep materi pelajaran itu sendiri. Pemahaman akan bertahan lama jika proses mendapatkannya dikonstruksi melalui pengalaman pribadi. Oleh karena itu, untuk menunjang peningkatan pemahaman mahasiswa terhadap matematika diperlukan suatu pendekatan pembelajaran yang sesuai.

Salah satu pendekatan yang tepat agar mahasiswa dapat mengkonstruksi sendiri pengetahuannya adalah dengan pendekatan konstruktivisme. Pendekatan konstruktivisme merujuk pada kurikulum 2013. Dalam kurikulum 2013 dikenal dengan pendekatan saintifik yang sebenarnya merupakan implementasi dari teori belajar kontruktivisme (Waseso, 2018). Menurut Barlia (2011) konstruktivisme merupakan pendekatan yang menekankan pada pentingnya keterlibatan peserta didik dalam proses pembelajaran, serta pentingnya pengetahuan awal untuk membantu memahami konsep pada proses pembelajaran. Dalam penelitian ini, dosen menggunakan pendekatan konstruktivisme melalui penggunaan buku teks. Buku teks yang digunakan dosen merupakan buku hasil penelitian pengembangan yang dilakukan oleh Yunita, dkk. (2019) yang sudah diterbitkan. Setiap bab pada buku ini berusaha membangun pengetahuan siswa melalui pengetahuan yang telah mereka miliki sebelumnya. Pada bagian pendahuluan di setiap bab disajikan masalah dalam kehidupan nyata yang dirancang untuk mengkonstruk pengetahuan mahasiswa dan mengantarkan mereka untuk masuk ke materi inti. Kemudian, pada bagian materi diberikan teori dasar dan beberapa masalah sekaligus arahan agar mereka dapat membangun konsep terhadap materi lebih mendalam. Untuk mengetahui seberapa jauh pemahaman mahasiswa terhadap materi, di bagian akhir bab diberikan latihan.

Beberapa penelitian yang menganalisis pembelajaran dengan menggunakan bahan ajar berbasis konstruktivisme dalam matematika telah banyak dilakukan. Diantaranya adalah penelitian yang dilakukan oleh Khairani \& Yenti (2018), penelitian ini bertujuan untuk 
melihat efektivitas penggunaan bahan ajar Matematika Diskrit berbasis konstruktivisme. Hasil penelitiannya menunjukkan bahwa bahan ajar matematika diskrit berbasis konstruktivisme efektif digunakan untuk perkuliahan, hal ini terlihat dari rata-rata hasil ujian mahasiswa yang berada pada tingkat baik. Selanjutnya, penelitian Khaidir (2019) menganalisis tentang efektivitas penggunaan buku ajar Metode Numerik berbasis konstruktivisme, hasil penelitiannya menunjukkan bahwa hasil belajar mahasiswa dengan menggunakan buku ajar berbasis konstruktivisme mengalami peningkatan. Terakhir, penelitian Yunita, Hamdunah, dan Sovia (2017) menganalisis pengaruh penggunaan buku teks dengan pendekatan konstruktivisme, disimpulkan bahwa penggunaan buku teks matematika dasar dengan pendekatan konstruktivisme memberikan pengaruh yang signifikan terhadap hasil belajar.

Secara umum, penelitian-penelitian terdahulu banyak meneliti tentang efektivitas penggunaan bahan ajar berbasis konstruktivisme dan bagaimana pengaruhnya terhadap hasil belajar. Sehingga, penelitian ini fokus untuk menganalisis bagaimana pemahaman konsep mahasiswa setelah belajar dengan menggunakan buku teks berpendekatan konstruktivisme khususnya pada mata kuliah Matematika Dasar materi sistem bilangan riil.

\section{Metode}

Penelitian ini adalah penelitian deskriptif dengan menggunakan pendekatan kualitatif. Penelitian kualitatif merupakan penelitian yang dilakukan dalam kondisi alami, tanpa diberikan perlakuan, sehingga memungkinkan peneliti untuk mengamati subjek secara detail (Mohajan, 2018; Hatch, 2002). Partisipan dalam penelitian ini adalah 17 orang mahasiswa STKIP PGRI Sumatera Barat yang mengambil mata kuliah Matematika Dasar yang dipilih dengan menggunakan teknik total sampling. Peneliti menggunakan total sampling karena hanya ada satu kelas untuk mata kuliah Matematika Dasar, jadi populasi sekaligus menjadi sampel (partisipan) secara otomatis.

Instrumen yang digunakan berupa tes, terdiri dari 10 butir soal yang diambil dari buku teks dengan pendekatan konstuktivisme. Soal dipilih dengan memperhatikan indikator pemahaman konsep. Indikator pemahaman konsep yang dipakai pada penelitian ini merujuk pada teori Hendriana, Roehati, \& Sumarmo (2017), yaitu: (1) menggunakan model, diagram dan simbol-simbol untuk merepresentasikan suatu konsep; (2) mengubah suatu bentuk representasi ke bentuk lainnya; (3) menggunakan konsep dalam penyelesaian pertidaksamaan suatu variable; (4) mengenal syarat yang menentukan suatu konsep; (5) dan mengidentifikasi 
sifat-sifat suatu konsep dan mengenal syarat yang menentukan konsep. Soal pemahaman konsep yang diberikan dapat dilihat pada Tabel 1.

Tabel 1. Soal Indikator Pemahaman Konsep Matematis

\section{Indikator Pemahaman Matematis}

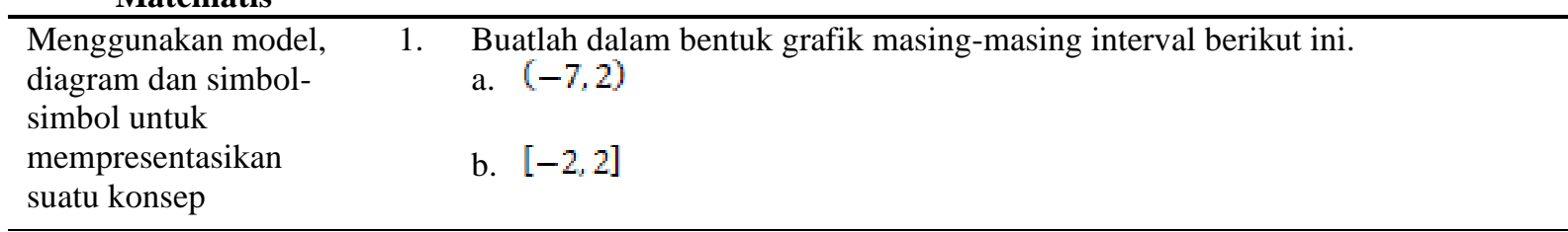

representasi ke bentuk $\quad$ a.

lainnya

a.

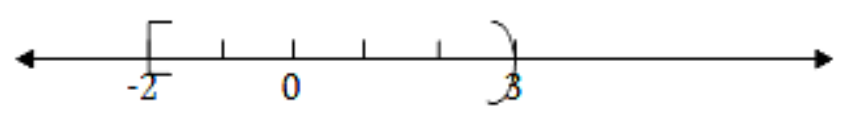

b.

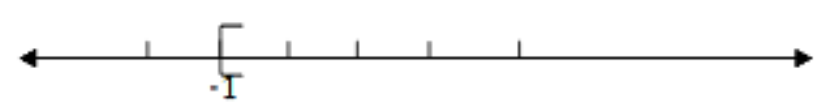
Menggunakan konsep
dalam penyelesaian
pertidaksamaan satu
variabel
3. Carilah himpunan penyelesaian dari pertidaksamaan berikut ini.
a. $\frac{x-2}{x+4}<2$

b. $3 x+4>5 x+2$
Mengenal syarat yang menentukan suatu

konsep
4. Selesaikanlah soal pertidaksamaan dibawah ini.
a. $|2 x+4| \geq 10$
b. $|3 x-1|<2|x+6|$

Mengidentifikasi sifatsifat suatu konsep dan mengenal syarat yang menentukan suatu konsep
5. Selesaikanlah soal pertidaksamaan dibawah ini.
a. $2<\left|\frac{x-5}{3}\right|<4$
b. $-6<2 x+3<-1$

(Yunita dkk., 2019)

Sepuluh butir soal ini merupakan soal pada materi sistem bilangan riil, yaitu: tentang interval bilangan riil, pertidaksamaan, dan pertidaksamaan nilai mutlak. Soal ini diambil dari buku teks dengan pendekatan konstruktivisme yang sudah dikembangkan pada penelitian sebelumnya, buku teks sudah divalidasi oleh para ahli.

Penelitian diawali dengan memberikan soal kepada mahasiswa yang belajar dengan menggunakan buku teks berbasis konstruktivisme. Waktu yang diberikan untuk mengerjakan 10 butir soal ini adalah selama 90 menit. Setelah itu, hasil pekerjaan mahasiswa dinilai, 
dihitung pencapaian pemahaman konsep untuk setiap indikator, kemudian dianalisis secara deskriptif.

\section{Hasil Penelitian}

Setelah soal dikerjakan oleh mahasiswa, jawaban siswa dianalisis berdasarkan indikator yang telah ditentukan. Berdasarkan hasil analisis persentase pemahaman konsep mahasiswa dapat dilihat pada Tabel 2.

Tabel 2. Persentase Pencapaian Pemahaman Konsep

\begin{tabular}{|c|c|c|c|}
\hline Indikator & No Soal & $\begin{array}{c}\text { Persentase } \\
(\%)\end{array}$ & $\begin{array}{c}\text { Rata-rata } \\
\text { Persentase }(\%)\end{array}$ \\
\hline \multirow{2}{*}{1} & $1 . \mathrm{a}$ & 71,4 & \multirow[t]{2}{*}{71,4} \\
\hline & $1 . b$ & 71,4 & \\
\hline \multirow{2}{*}{2} & $2 . a$ & 65,7 & \multirow[t]{2}{*}{60,7} \\
\hline & 2.b & 55,7 & \\
\hline \multirow{2}{*}{3} & $3 . a$ & 37,1 & \multirow[t]{2}{*}{45,0} \\
\hline & $3 . b$ & 52,9 & \\
\hline \multirow{2}{*}{4} & $4 . \mathrm{a}$ & 35,7 & \multirow[t]{2}{*}{31,4} \\
\hline & 4.b & 27,1 & \\
\hline \multirow{2}{*}{5} & $5 . \mathrm{a}$ & 25,7 & \multirow{2}{*}{36,4} \\
\hline & $5 . \mathrm{b}$ & 47,1 & \\
\hline
\end{tabular}

Berdasarkan Tabel 2 persentase pencapaian pemahaman konsep tertinggi adalah pada indikator pertama, artinya sebagian mahasiswa sudah mampu menggunakan model, diagram dan simbol-simbol untuk mempresentasikan suatu konsep. Hal ini dapat dilihat dari jawaban mahasiswa pada Gambar 2.

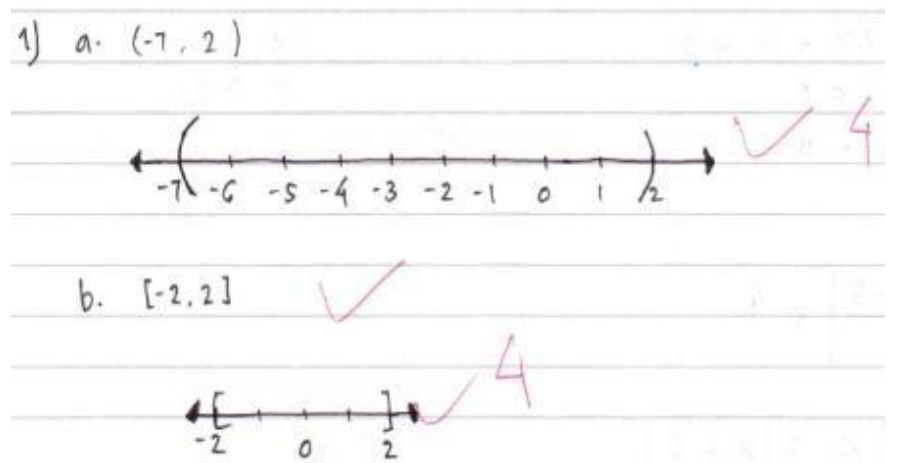

Gambar 2. Jawaban Mahasiswa untuk Indikator Pertama

Jawaban pada Gambar 2 menunjukkan bahwa mahasiswa mampu mengubah bentuk interval ke dalam bentuk grafik, mahasiswa sudah memahami konsep interval tertutup dan interval terbuka. 
Selanjutnya, indikator mengubah suatu bentuk representasi ke bentuk lainnya, dalam hal ini yang diubah adalah bentuk grafik ke bentuk interval, persentase pencapaiannya sebesar $60,7 \%$.

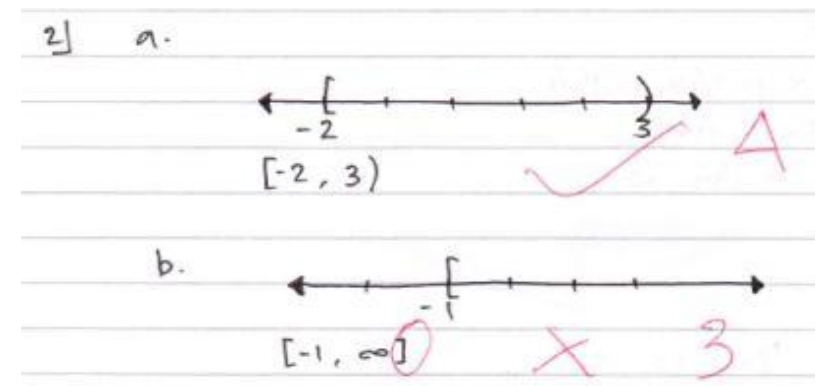

Gambar 3. Jawaban Mahasiswa untuk Indikator Kedua

Gambar 3 menunjukkan bahwa pada soal No. 2a mahasiswa dapat merepresentasikan bentuk grafik ke dalam bentuk interval. Namun, pada soal No. 2b mahasiswa melakukan kesalahan dengan menempatkan kurung siku pada disebelah tak hingga, seharusnya kurung yang digunakan adalah kurung biasa.

Selanjutnya, indikator menggunakan konsep dalam penyelesaian pertidaksamaan satu variabel persentase pencapaiannya tergolong rendah, yaitu hanya 45,0\%. Hal ini menunjukkan bahwa masih terdapat banyak kesalahan yang dilakukan oleh mahasiswa dalam menggunakan konsep untuk menyelesaikan masalah pertidaksamaan. Salah satu bentuk kesalahan mahasiswa dapat dilihat pada Gambar 4.

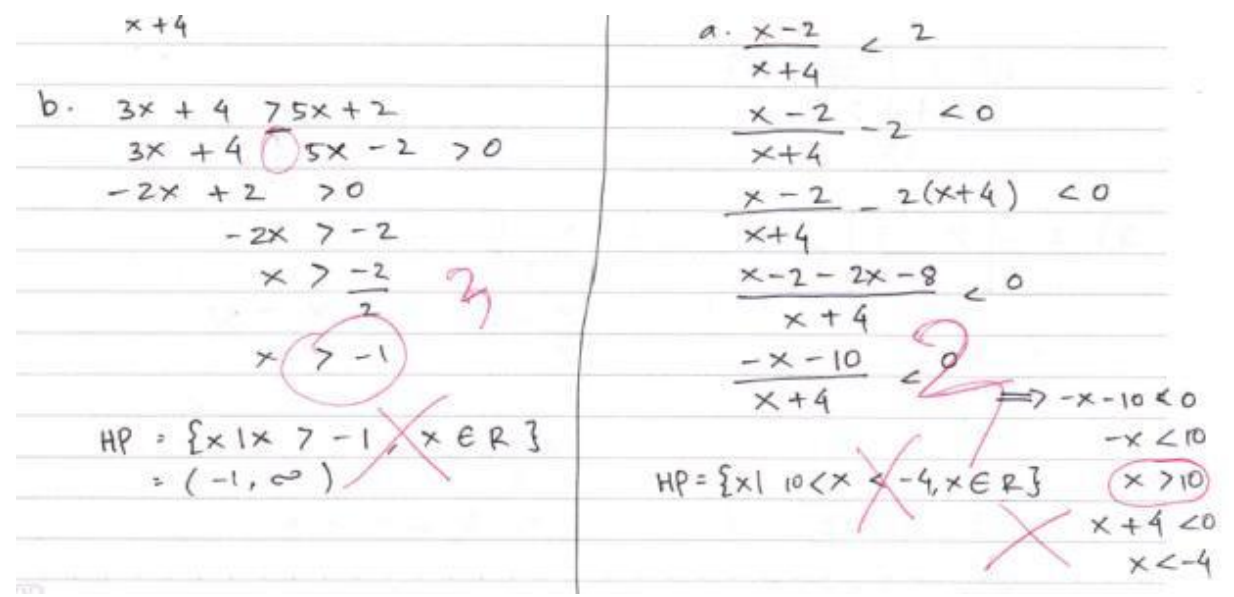

Gambar 4. Jawaban Mahasiswa untuk Indikator Ketiga

Jawaban No. 3a menunjukkan bahwa mahasiswa sudah mengetahui langkah awal yang harus dilakukan untuk menyelesaikan soal pertidaksamaan, yaitu dengan menambahkan masingmasing ruas dengan bilangan yang sama, kemudian menyamakan penyebut. Namun, dalam menentukan daerah penyelesaian mahasiswa melakukan kekeliruan, seharusnya mahasiswa terlebih dahulu menentukan pembuat nol, kemudian menentukan daerah penyelesaiannya. 
Begitu juga untuk jawaban No. 3b, mahasiswa belum memahami konsep tentang cara menentukan daerah penyelesaian.

Jawaban No. 4 dengan indikator mengenal syarat yang menentukan suatu konsep. Pada soal ini mahasiswa diminta untuk menyelesaikan soal pertidaksamaan nilai mutlak. Hasil jawaban siswa tergambar pada gambar berikut ini.
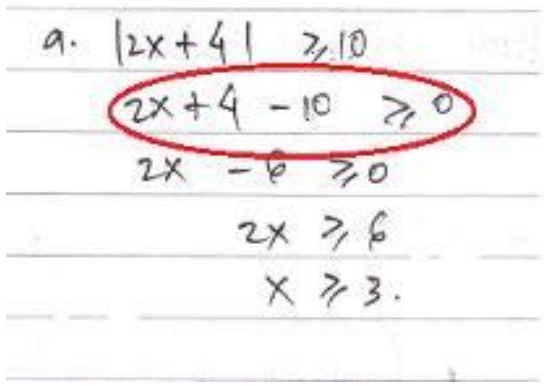

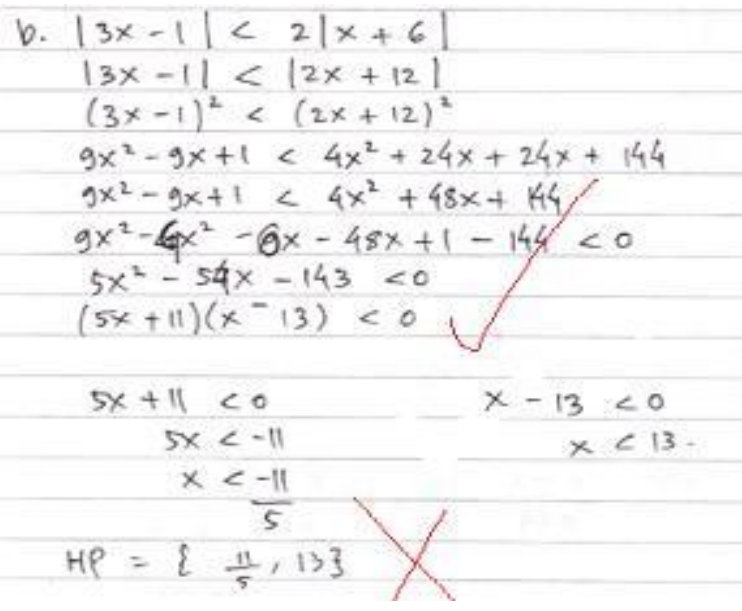

Gambar 5. Jawaban Mahasiswa untuk Indikator keempat

Nomor $4 \mathrm{a}$ dan $4 \mathrm{~b}$ belum diselesaikan dengan tuntas oleh mahasiswa. Jawaban No. 4a seharusnya masing-masing ruas dikuadratkan, sehingga membentuk pertidaksamaan kuadrat, tentukan titik pembuat nol, kemudian cari daerah penyelesaiannya. Hal ini menunjukkan bahwa mahasiswa tidak memahami syarat untuk menyelesaikan pertidaksamaan nilai mutlak. Untuk jawaban No. 4b, pada awalnya mahasiswa sudah memberikan jawaban yang benar, namun pada bagian akhir mahasiswa tidak dapat menentukan himpunan penyelesaiannya. Sama halnya dengan No. 3, masalah utama pada No. 4 ini adalah mahasiswa belum memahami bagaimana konsep untuk menentukan himpunan penyelesaian, mahasiswa lupa untuk menentukan titik pembuat not sebelum menentukan daerah penyelesaian. Presentase penguasaan pemahaman konsep untuk soal ini merupakan yang paling rendah diantara penguasaan indikator lainnya.

Soal terakhir terkait dengan indikator mengidentifikasi sifat-sifat suatu konsep dan mengenal syarat yang menentukan suatu konsep. 


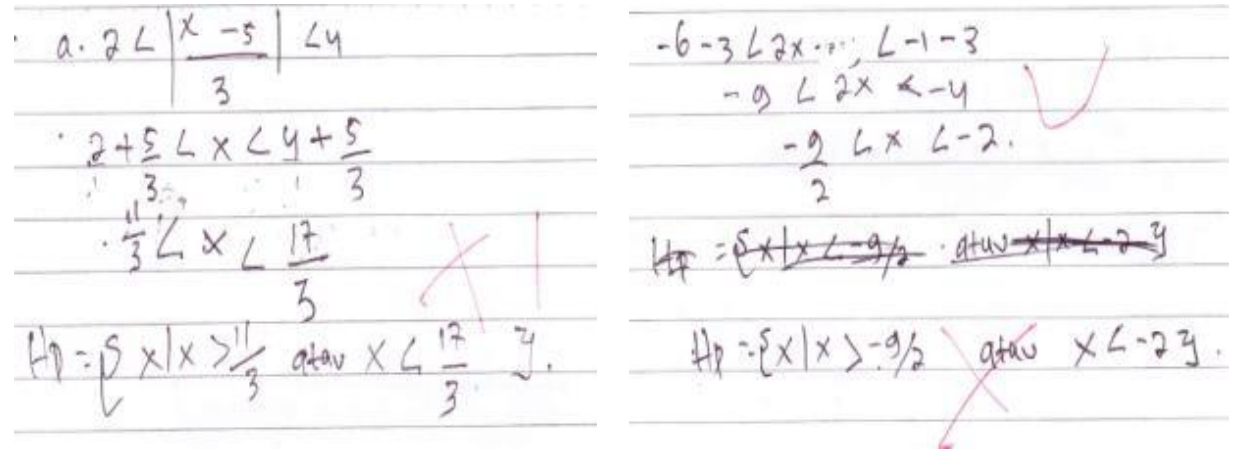

Gambar 6. Jawaban Mahasiswa untuk Indikator Kelima

Gambar 6 menunjukkan bahwa pada jawaban No. 5a mahasiswa tidak dapat mengidentifikasi sifat-sifat nilai mutlak, mahasiswa menghilangkan tanda mutlak tanpa memperhatikan sifatsifatnya, sehingga menyebabkan kesalahan sampai akhir. Pada jawaban No. 5b, mahasiswa pada tahap awal sudah dapat menyederhanakan pertidaksamaan, namun tidak dapat menuntaskan jawaban sampai akhir dengan benar. Mahasiswa masih belum paham bagaimana menentukan himpunan penyelesaian dari suatu pertidaksamaan.

\section{Pembahasan}

Pemahaman konsep matematis adalah salah satu tujuan penting dalam pembelajaran matematika, hal ini memberikan pengertian bahwa materi-materi yang diajarkan kepada mahasiswa bukan hanya sebagai hapalan, namun lebih dari itu dengan pemahaman mahasiswa dapat lebih mengerti akan konsep materi pelajaran itu sendiri. Kemampuan pemahaman konsep matematis mahasiswa akan berdampak positif terhadap peningkatan hasil belajar Alim, Umam, dan Rohim (2015) dan sebaliknya pemahaman konsep yang rendah akan menjadi salah satu penyebab rendahnya prestasi belajar mahasiswa (Ardila \& Hartanto, 2017). Salah satu materi perkuliahan Matematika Dasar yang dianggap sulit oleh sebagian besar mahasiswa adalah materi tentang sistem bilangan riil. Sucipto dan Mauliddin (2017) dalam penelitiannya juga menyatakan bahwa salah satu materi yang sulit dipahami mahasiswa adalah tentang konsep bilangan riil.

Salah satu usaha yang dilakukan dosen untuk membantu memaksimalkan pemahaman konsep pada materi sistem bilangan riil adalah dengan melakukan proses pembelajaran dengan berbantuan buku teks dengan pendekatan konstruktivisme. Berdasarkan hasil penelitian yang ditemukan, rata-rata persentase pencapaian pemahaman konsep pada dua indikator (indikator 1 dan 2) sudah melebihi 50\%, sebagian besar mahasiswa sudah mampu merepresentasikan bentuk interval ke dalam bentuk grafik dan sebaliknya. Hal ini 
mengindikasikan bahwa ada pengaruh positif penggunaan buku teks berbasis konstruktivisme terhadap kemampuan pemahaman konsep mahasiswa pada dua indikator tersebut. Senada dengan hasil penelitian Nizarwati, Hartono, dan Aisyah (2013); Priartini, Hendriani, dan Fitriani (2017) yang menyatakan bahwa perangkat pembelajaran berbasis konstruktivisme efektif digunakan untuk meningkatkan kemampunan pemahaman konsep. Selain itu, persentase pencapaian pemahaman konsep mahasiswa tergolong tinggi pada kedua indikator tersebut juga disebabkan oleh tingkat kesukaran soal pada dua nomor ini termasuk rendah, jadi mahasiswa tidak terlalu kesulitan dalam mengerjakannya.

Sedangkan tiga indikator lainnya (indikator 3, 4, dan 5) persentase pencapaian pemahaman konsep masih di bawah 50\%, dapat diartikan bahwa untuk tiga indikator ini belum dikuasai sepenuhnya oleh mahasiswa. Pada indikator 3 soal nomor 3, kesalahan terjadi disebabkan oleh ketidakpahaman mahasiswa tentang titik pembuat nol, ini mengakibatkan terjadinya kesalahan dalam menentukan himpunan penyelesaian. Pada soal nomor 4a indikator ke empat, kesalahan terjadi dikarenakan mahasiswa tidak mengenal syarat-syarat untuk menyelesaikan pertidaksamaan yang memuat tanda mutlak. Pertidaksamaan nilai mutlak dapat diselesaikan dengan terlebih dahulu menghilangkan tanda mutlaknya. Cara menghilangkan tanda mutlak tersebut mengikuti aturan berikut.

Untuk setiap $a \geq 0$ maka

1. $|x| \leq a$ jika dan hanya jika $-a \leq x \leq a$ dan $x^{2} \leq a^{2}$

2. $|x| \geq a$ jika dan hanya jika $x \geq a$ atau $x \leq-a$ dan $x^{2} \geq a^{2}$ (Sovia, dkk., 2019; Yunita dkk., 2019)

Untuk menjawab soal nomor 4a dapat digunakan aturan nomor 2, sedangkan untuk nomor $4 \mathrm{~b}$ dapat digunakan aturan nomor 1 . Pada jawaban nomor $4 \mathrm{~b}$, mahasiswa sudah memilih aturan yang tepat, namun keliru dalam menentukan himpunan penyelesaian seperti pada jawaban nomor 3. Untuk soal nomor 5, mahasiswa memberikan jawaban tanpa memperhatikan sifat-sifat suatu konsep. Pada soal nomor 5a terjadi kesalahan dari awal jawaban sampai akhir, mahasiswa seharusnya dapat memanfaatkan kedua sifat nilai mutlak untuk menyelesaikan soal ini. Sedangkan untuk soal nomor 5b, mahasiswa melakukan kesalahan saat menuliskan penyelesaian dalam bentuk himpunan. Himpunan penyelesaian untuk soal tersebut dapat ditulis seperti berikut.

$$
H P=\left\{x \mid-\frac{9}{2}<x<-2, x \in \mathbb{R}\right\}
$$

Berdasarkan jawaban mahasiswa, kesalahan yang banyak terjadi adalah dalam menentukan himpunan penyelesaian pertidaksamaan, mahasiswa tidak menentukan terlebih 
dahulu titik pembuat nol sebelum menentukan himpunan penyelesaian, mereka masih belum memahami konsep daerah penyelesaian dari pertidaksamaan. Selain itu, mahasiswa juga belum memahami sifat-sifat nilai mutlak, sehingga mereka kesulitan untuk menyederhanakan bentuk pertidaksamaan yang memuat nilai mutlak.

\section{Simpulan}

Mahasiswa yang belajar menggunakan buku dengan pendekatan konstruktivisme masih mengalami kesulitan dalam menentukan himpunan penyelesaian dari suatu pertidaksamaan, termasuk pertidaksamaan nilai mutlak saat mengerjakan soal. Mahasiswa belum memahami konsep tentang titik pembuat nol dan daerah penyelesaian. Namun, pada pokok bahasan interval, pemahaman mahasiswa sudah baik. Mahasiswa dapat mengubah interval ke dalam bentuk grafik dan sebaliknya.

\section{Referensi}

Alim, E. S., Umam, K., \& Rohim, S. (2015). Integration of reciprocal teaching-ICT model to improve students' mathematics critical thinking ability. In Workshop Proceedings of the 23rd International Conference on Computers in Education, ICCE 2015.

Amir, M. F. (2017). Identifikasi kesulitan mahasiswa dalam memecahkan masalah open ended materi nilai mutlak. Jurnal Mercumatika: Jurnal Penelitian Matematika dan Pendidikan Matematika, 2(2), 1-15. https://doi.org/10.26486/jm.v2i2.291.

Ardila, A., \& Hartanto, S. (2017). Faktor yang mempengaruhi rendahnya hasil belajar matematika siswa MTs Iskandar Muda Batam. PYTHAGORAS: Jurnal Program Studi Pendidikan Matematika, 6(2), 175-186. https://doi.org/10.33373/pythagoras.v6i2.966.

Barlia, L. (2011). Konstruktivisme dalam pembelajaran sains di SD: tinjauan epistimologi, ontologi, dan keraguan dalam praksisnya. Cakrawala Pendidikan, 3(3), 343-358.

Delphie, B. (2009). Matematika untuk anak berkebutuhan khusus. Sleman: PT. Intan Sejati Klaten.

Godino, J. D. (2015). Mathematical concepts, their meaning, and understanding. Proceeding of Conference of International Group for the Psychology of Mathematics Education, 2(March), 417-425.

Hatch, J. A. (2002). Doing qualitative research in education setting. In State University of New York Press, Albany (Vol. 1). State University of New York Press.

Hendriana, Roehati, \& Sumarmo. (2017). Hard skills dan soft skills. Bandung: PT. Refika Aditama.

Khaidir, C. (2019). Efektivitas buku ajar metode numerik berbasis konstruktivisme di IAIN Batusangkar. Jurnal Saintika Unpam: Jurnal Sains dan Matematika Unpam, 2(2), 109114. https://doi.org/10.32493/jsmu.v2i2.3321.

Khairani, M., \& Yenti, F. (2018). Efektifitas bahan ajar mata kuliah matematika diskrit berbasis konstruktivisme. Suska Journal of Mathematics Education, 4(2), 100-107.

Lambertus. (2016). Developing skills understanding of mathematical high school student. International Journal of Education Research, 4(7), 315-326.

Minarni, A., Napitupulu, E. E., \& Husein, R. (2016). Mathematical understanding and 
representation ability of public junior high school in North Sumatera. Journal on Mathematics Education, 7(1), 45-58.

Mohajan, H. (2018). Properties of transitions observed in the 161Tb decay. Journal of Economic Development, Environment and People, 7(01), 23-48.

Nizarwati, N., Hartono, Y., \& Aisyah, N. (2013). Pengembangan perangkat pembelajaran berorientasi konstruktivisme untuk mengajarkan konsep perbandingan trigonometri siswa kelas X SMA. Jurnal Pendidikan Matematika, 3(2). https://doi.org/10.22342/jpm.3.2.328.

Priartini, D. A., Hendriani, A., \& Fitriani, A. D. (2017). Penerapan model konstruktivisme untuk meningkatkan pemahaman konsep bangun ruang peserta didik SD. Jurnal Pendidikan Guru Sekolah Dasar, 1(1), 26-35.

Rahmawati, A. (2017). Analisis kesalahan mahasiswa pendidikan matematika dalam menyelesaikan soal pertidaksamaan pada mata kuliah Kalkulus I. Jurnal Pendidikan Matematika, 8(1), 81-90. https://doi.org/10.1017/CBO9781107415324.004.

Sovia, A., Harisman, Y., Rifa'i, H., \& Rahima. (2019). Modul kalkulus berbasis masalah. Padang: ERKA.

Stylianides, A. J., \& Stylianides, G. J. (2014). Learning mathematics with understanding: a critical consideration of the learning principle in the principles and standards for school mathematics learning mathematics with understanding: a critical consideration of the learning principle in the princi. TMME, 4(January 2007), 103.

Sucipto, L., \& Mauliddin, M. (2017). Analisis kesulitan belajar mahasiswa dalam memahami konsep bilangan real. Beta Jurnal Tadris Matematika, 9(2), 197. https://doi.org/10.20414/betajtm.v9i2.37.

Waseso, H. P. (2018). Kurikulum 2013 dalam persektif teori pembelajaran konstruktivis. Ta'lim: Jurnal Studi Pendidikan Islam, 1(1), 59-72.

Yunita, A., Hamdunah, \& Sovia, A. (2017). Pengaruh penggunaan buku teks dengan pendekatan konstruktivisme. Seminar Nasional Pendidikan Matematika (SNPM), (November), 36-42.

Yunita, A., Imelwaty, S., Hamdunah, \& Sovia, A. (2019). Matematika dasar buku teks bilingual dengan pendekatan konstruktivisme. Padang: ERKA. 